\title{
Nitrogen Uptake Efficiency and Total Soil Nitrogen Accumulation in Long-Term Beef Manure and Inorganic Fertilizer Application
}

\author{
Peter Omara $\mathbb{D}^{1,2}$ Lawrence Aula ${ }^{1}{ }^{1},{ }^{1}$ and William R. Raun ${ }^{1}{ }^{1}$ \\ ${ }^{1}$ Department of Plant and Soil Sciences, Oklahoma State University, 74078 Stillwater, OK, USA \\ ${ }^{2}$ Department of Agronomy, Gulu University, P.O. Box 166, Gulu, Uganda \\ Correspondence should be addressed to Peter Omara; peter.omara@okstate.edu
}

Received 22 December 2018; Revised 22 April 2019; Accepted 20 May 2019; Published 20 June 2019

Guest Editor: Nunzio Fiorentino

Copyright (C) 2019 Peter Omara et al. This is an open access article distributed under the Creative Commons Attribution License, which permits unrestricted use, distribution, and reproduction in any medium, provided the original work is properly cited.

Livestock manure is a common soil amendment for crop-livestock production systems. However, the efficiency of crop nitrogen $(\mathrm{N})$ uptake from the manure-amended soil may not equate with that from inorganic $\mathrm{N}$ sources. The objective of this paper was to determine the efficiency of $\mathrm{N}$ uptake, grain yield, and total soil nitrogen (TSN) accumulation in beef manure-amended soil compared to the inorganic N fertilizer-amended soil. Data (1990-2015) from a long-term continuous winter wheat (Triticum aestivum L.) fertility experiment at Stillwater in Oklahoma, USA, were used in this report. Three of the six "Magruder Plot" treatments used in this study were manure, NPK plus lime (NPKL), and a check (no nutrients applied). Pre-plant N, P, and K were applied annually at $67,14.6$, and $27.8 \mathrm{~kg} \cdot \mathrm{ha}^{-1}$, respectively, while beef manure was applied every 4 years at $269 \mathrm{~kg} \mathrm{~N} \cdot \mathrm{ha}{ }^{-1}$. The results indicated that grain $\mathrm{N}$ uptake in the manure treatment $\left(48.1 \mathrm{~kg} \cdot \mathrm{ha}^{-1}\right)$ was significantly $(p<0.05)$ lower than that in the NPKL treatment $\left(60.2 \mathrm{~kg} \cdot \mathrm{ha}^{-1}\right)$. This represents $20.1 \%$ efficiency of inorganic $\mathrm{N}$ uptake than the manure $\mathrm{N}$ uptake. The average grain yield (1990-2015) from the manure and NPKL treatments was 2265.7 and $2510.5 \mathrm{~kg} \cdot \mathrm{ha}^{-1}$, respectively, and was not significantly different. There was a trend of TSN increase over the study period for both manure and NPKL treatments. The average TSN from manure and NPKL treatments was 0.92 and $0.91 \mathrm{~g} \cdot \mathrm{kg}^{-1}$ soil, respectively, and was not significantly different. While no significant difference between manure and NPKL grain yield was observed, there was a significantly lower uptake efficiency of manure N compared to inorganic N. Furthermore, the low uptake efficiency of the manure N could suggest a potential for environmental pollution. Appropriate timing and application rate of manure $\mathrm{N}$ sources could optimize crop use efficiency and limit potential threat to the environment.

\section{Introduction}

Nitrogen $(\mathrm{N})$ is an important plant nutrient and commonly the most deficient in many intensive cereal monocropping systems. Additions from both synthetic and animal manures help supplement the native $\mathrm{N}$ pool from organic matter mineralization and/or rainfall supply $[1,2]$. However, applications in excess of plant requirements from both sources have been blamed for aboveground environmental pollution $[3,4]$. Environmental pollution from synthetic $\mathrm{N}$ sources has been extensively investigated, and attempts have been made to compare it with that coming from manure. By virtue of its popular use especially under large-scale crop production, synthetic $\mathrm{N}$ sources are believed to cause the greatest threat to the environment. Inorganic sources are readily available and can be taken up by plants and/or lost within the soil system [5]. Manure N, on the contrary, has N mostly bound within organic fractions that require some kind of degradation so as to release available plant $\mathrm{N}[6,7]$. Accordingly, synthetic $\mathrm{N}$ could potentially cause more of an environmental threat relative to manure N. Some studies however note that animal manure $\mathrm{N}$ may comparatively lead to more environmental pollution depending on the source, rate, and timing of application [3, 8]. For instance, Chang and Entz [9] reported soil and groundwater contamination with increased leaching of $\mathrm{NO}_{3}-\mathrm{N}$ in applied beef manure where 
annual losses of nitrogen ranged from 93 to $341 \mathrm{~kg} \mathrm{~N} \cdot \mathrm{ha}^{-1}$. Losses were higher under irrigated treatments and when application exceeded annual recommended rates of $60 \mathrm{Mg} \cdot \mathrm{ha}^{-1}$ wet weight. Therefore, the efficiency of plant $\mathrm{N}$ uptake and potential TSN accumulation strongly depend on the rate and frequency of application.

Total soil $\mathrm{N}$ is one of the indicators of soil fertility in an agricultural ecosystem [10]. Earlier studies indicate that TSN in the surface layers of most cultivated soils varies between $0.6 \mathrm{~g} \cdot \mathrm{kg}^{-1}$ and $5 \mathrm{~g} \cdot \mathrm{kg}^{-1}$ although it could reach up to $25 \mathrm{~g} \cdot \mathrm{kg}^{-1}$ in peat [11]. Xu et al. [12] noted that this figure fluctuates depending on the land use and management system. Indisputably, agriculture takes a greater portion of the liability for the fluctuation. Several research reports present contrasting views on whether agriculture, particularly crop production, leads to a buildup or depletion of soil organic $N[10,12,13]$. Generally, it appears that continuous crop production without replenishing soil nutrients would certainly deplete soil resources [14]. On the contrary, intensive or high input production systems may lead to buildup of certain soil nutrients. Much as continuous crop production can cause significant loss in the quantity of soil organic matter and total N [15], certain crop production practices may lead to buildup of carbon and $\mathrm{N}$ within the soil system. For instance, Aula et al. [13] demonstrated from long-term trials that application of inorganic $\mathrm{N}$ fertilizer at rates above $90 \mathrm{~kg} \cdot \mathrm{ha}^{-1}$ can increase and lead to buildup of TSN. The excess $\mathrm{N}$ in the soil system may pose an environmental threat if certain weather variables favor its loss. From an environmental perspective, total soil N, in addition to total soil phosphorus, is the cause of nonpoint source pollution for surface and groundwater [12]. This is true especially when inorganic $\mathrm{N}$ constitutes a higher proportion of the total soil N. Leaching and surface runoff through erosion of $\mathrm{N}$ applied in excess of plant needs are the main mechanisms for environmental pollution.

Some research reports that continuous application of $\mathrm{N}$ fertilizer can increase the likelihood of TSN accumulation with time [16]. However, $\mathrm{N}$ from fertilizers in excess of plant requirements is not the only factor in the equation. Biological processes such as symbiotic and nonsymbiotic $\mathrm{N}_{2}$ fixation in addition to atmospheric $\mathrm{N}$ in rainfall contribute a substantial amount of TSN [17, 18]. These biological or natural processes, which significantly influence soil $\mathrm{N}$ availability and subsequently crop yield, are independent of $\mathrm{N}$ fertilizer application rates and largely controlled by the environment [19]. In addition to atmospheric $\mathrm{N}_{2}$ fixation, microorganisms contribute to the availability of mineral $\mathrm{N}$ under favorable soil temperature, moisture, and aeration. Free-living decomposer microbes convert organic matter into nutrients for plants and other microorganisms, while rhizosphere organisms are symbiotically associated with plant roots and free-living $\mathrm{N}$ fixers [20]. These microorganisms are capable of extracting $\mathrm{N}$ from organic matter and other soil substances and subsequently releasing available plant $\mathrm{N}$ to the soil pool. Knops and Tilman [15] studied $\mathrm{N}$ and carbon dynamics in an abandoned field and reported that the rate of $\mathrm{N}$ accumulation depended on atmospheric deposition and symbiotic fixation by legumes. Jurgensen
[21] reported that $\mathrm{N}$ fixation by autotrophic microorganisms can reach $70 \mathrm{~kg} \cdot \mathrm{ha}^{-1} \cdot \mathrm{yr}^{-1}$. Therefore, $\mathrm{N}$ from the soil pool is subject to either plant uptake or various loss pathways. If $\mathrm{N}$ supply from fertilizer, symbiotic or nonsymbiotic fixation, and/or straw mineralization exceeds plant requirements, significant quantities can be either lost or immobilized. Immobilization, which is a biological process, is in turn dictated by environmental conditions. This is the reason for TSN accumulation under continuous fertilizer $\mathrm{N}$ application.

\section{Materials and Methods}

The Magruder Plots located at Stillwater in Oklahoma, USA, is a long-term continuous winter wheat (Triticum aestivum L.) fertility experiment situated on a Kirkland silt loam (fine, mixed, thermic Udertic Paleustolls). The experiment was started by Alexander C. Magruder and included a manure treatment that was started in 1892, while inorganic fertilizer treatments were initiated in 1929 [22]. The six treatments included in this long-term experiment are manure, $\mathrm{P}, \mathrm{NP}$, NPK, NPK plus lime (NPKL), and an unfertilized check plot, where no nutrients have been applied. However, only three treatments (manure, NPKL, and check) were used for this report. Plot sizes are $30 \mathrm{~m}$ by $5 \mathrm{~m}$. Inorganic chemical fertilizer treatments were applied every year prior to planting. Nitrogen was applied as urea (46-0-0) at a rate of $67 \mathrm{~kg} \mathrm{~N} \cdot \mathrm{ha}^{-1}$, P was applied at $14.6 \mathrm{~kg} \mathrm{P} \cdot \mathrm{ha}^{-1}$, and $\mathrm{K}$ was applied at $27.8 \mathrm{~kg} \mathrm{~K} \cdot \mathrm{ha}^{-1}$, while beef manure was applied every 4 years at $269 \mathrm{~kg} \mathrm{~N} \cdot \mathrm{ha}^{-1}$ (Table 1). Therefore, similar quantities of $\mathrm{N}(269 \mathrm{~kg})$ were provided both in the manuretreated and inorganic $\mathrm{N}$-treated plots during a four-year period in which manure was applied once. Lime was applied when soil pH dropped below 5.5.

It is important to note that, at the time of establishment of this long-term experiment, modern statistics did not exist. Consequently, replications were not included in the experimental design. However, a long-term study of this nature can be used as a basis for understanding the effect of manure application and general agronomic management including yield potentials as well as losses of crop nutrient elements. For this work, only data from 1990 to 2015 were used due to availability of data on total soil N. Wheat grain was harvested with a Massey Ferguson 8XP combine and yield data recorded for each year reported in this study. Wheat subsamples were taken and oven-dried at $105^{\circ} \mathrm{C}$ for 24 hours. These samples were then ground to pass a $1 \mathrm{~mm}$ mesh size. Total elemental grain $\mathrm{N}$ for each sample, expressed as a percent, was determined using dry combustion analysis (LECO TruSpec) [23]. Each year, postharvest soil samples were also taken, oven-dried, and ground for TSN analysis. Grain N uptake was determined by multiplying yield times grain $\mathrm{N}$ content and expressed in $\mathrm{kg} \cdot \mathrm{ha}^{-1}$ (Table 2). Analysis of variance was performed using the GLM procedure in SAS 9.4 [24], and means were separated using Tukey's HSD. Due to lack of replications, the study period (years) was used to estimate experimental error during analysis of variance. Comparisons were made between average grain yield, $\mathrm{N}$ uptake, and TSN for the 
TABle 1: Treatment structure, composition, and description for Magruder Plots located at Stillwater in Oklahoma, USA.

\begin{tabular}{|c|c|c|c|c|}
\hline Treatment & Composition & Description & Input sources & Form and quantity applied \\
\hline 1 & Manure & Cattle manure applied every 4 years & Cattle manure & Cattle manure $269 \mathrm{~kg} \mathrm{~N} \cdot \mathrm{ha}^{-1}$ \\
\hline 2 & - & Check, no nutrient applied & - & - \\
\hline 3 & $\mathrm{P}$ & $\mathrm{P}$ applied each year & TSP & $\mathrm{P}_{2} \mathrm{O}_{5}(0-34-0)$ \\
\hline 4 & NP & $\mathrm{N}$ and $\mathrm{P}$ applied each year & Urea, TSP & $\mathrm{N}, \mathrm{P}_{2} \mathrm{O}_{5}(67-34-0)$ \\
\hline 5 & NPK & $\mathrm{N}, \mathrm{P}$, and $\mathrm{K}$ applied each year & Urea, TSP, $\mathrm{KCl}$ & $\mathrm{N}, \mathrm{P}_{2} \mathrm{O}_{5}, \mathrm{~K}_{2} \mathrm{O}(67-34-34)$ \\
\hline 6 & NPKL & $\begin{array}{l}\mathrm{N}, \mathrm{P} \text {, and } \mathrm{K} \text { applied each year }+ \text { lime applied when } \\
\text { soil } \mathrm{pH}<5.5\end{array}$ & $\begin{array}{l}\text { Urea, TSP, } \\
\mathrm{KCl}+\text { Aglime }\end{array}$ & $\mathrm{N}, \mathrm{P}_{2} \mathrm{O}_{5}, \mathrm{~K}_{2} \mathrm{O}+$ lime $(67-34-34)$ \\
\hline
\end{tabular}

TABLE 2: Wheat grain yield $\left(\mathrm{kg} \cdot \mathrm{ha}^{-1}\right)$, grain $\mathrm{N}$ content $(\%), \mathrm{N}$ uptake $\left(\mathrm{kg} \cdot \mathrm{ha}{ }^{-1}\right)$, and total soil $\mathrm{N}\left(\mathrm{g} \cdot \mathrm{kg}^{-1}\right.$ soil) of Magruder Plots (1990-2015) located at Stillwater in Oklahoma, USA.

\begin{tabular}{|c|c|c|c|c|c|c|c|c|c|c|c|c|}
\hline \multirow{2}{*}{ Year } & \multicolumn{3}{|c|}{ Grain yield $\left(\mathrm{kg} \cdot \mathrm{ha}^{-1}\right)$} & \multicolumn{3}{|c|}{ Grain N (\%) } & \multicolumn{3}{|c|}{$\mathrm{N}$ uptake $\left(\mathrm{kg} \cdot \mathrm{ha}^{-1}\right)$} & \multicolumn{3}{|c|}{ Total soil $\mathrm{N}$ (g.kg ${ }^{-1}$ soil) } \\
\hline & Manure & Check & NPKL & Manure & Check & NPKL & Manure & Check & NPKL & Manure & NPKL & Check \\
\hline 1990 & 2325.1 & 1451.5 & 2184.0 & 2.04 & 2.00 & 2.28 & 47.4 & 29.0 & 49.8 & 0.70 & 0.76 & 0.59 \\
\hline 1991 & 1753.9 & 1115.5 & 2963.5 & 2.33 & 2.04 & 2.44 & 40.8 & 22.8 & 72.2 & 0.70 & 0.76 & 0.59 \\
\hline 1992 & 1429.2 & 903.2 & 1973.7 & 2.17 & 1.96 & 2.35 & 31.0 & 17.7 & 46.4 & 0.74 & 0.77 & 0.60 \\
\hline 1993 & 2499.5 & 1259.6 & 2754.3 & 2.22 & 1.91 & 2.26 & 55.5 & 24.1 & 62.2 & 0.74 & 0.77 & 0.60 \\
\hline 1994 & 1510.1 & 628.4 & 1865.4 & 2.23 & 2.34 & 2.39 & 33.6 & 14.7 & 44.7 & 0.95 & 0.99 & 0.62 \\
\hline 1996 & 1669.2 & 967.7 & 1884.3 & 2.28 & 2.18 & 2.28 & 38.1 & 21.1 & 43.0 & 1.07 & 0.93 & 0.69 \\
\hline 1997 & 3454.1 & 1397.8 & 4186.6 & 2.28 & 2.18 & 2.28 & 78.8 & 30.5 & 95.5 & 1.17 & 1.07 & 0.69 \\
\hline 1998 & 2071.8 & 974.4 & 2591.9 & 2.31 & 2.03 & 2.43 & 47.9 & 19.8 & 63.0 & - & - & - \\
\hline 1999 & 2744.6 & 1767.5 & 2527.9 & 2.31 & 2.50 & 2.32 & 63.3 & 44.2 & 58.7 & - & - & - \\
\hline 2000 & 2473.4 & 1511.6 & 2377.7 & 2.25 & 1.80 & 2.12 & 55.7 & 27.3 & 50.3 & - & - & - \\
\hline 2001 & 2563.0 & 795.1 & 2663.8 & 2.32 & 2.24 & 2.30 & 59.5 & 17.8 & 61.1 & 0.59 & 0.68 & 0.52 \\
\hline 2002 & 2369.4 & 1212.0 & 2790.4 & 1.96 & 1.85 & 2.52 & 46.4 & 22.4 & 70.3 & 0.68 & 0.68 & 0.49 \\
\hline 2005 & 2956.8 & 1209.6 & 2956.8 & 2.43 & 1.96 & 3.02 & 72.0 & 23.7 & 89.2 & - & - & - \\
\hline 2006 & 2225.1 & 1414.8 & 3112.7 & 2.14 & 2.02 & 2.65 & 47.6 & 28.5 & 82.4 & 1.09 & 0.98 & 0.74 \\
\hline 2008 & 3473.6 & 1823.5 & 3281.4 & 1.74 & 1.91 & 2.21 & 60.5 & 34.9 & 72.5 & - & - & - \\
\hline 2009 & 166.7 & 330.0 & 357.5 & 2.12 & 1.92 & 2.08 & 3.5 & 6.3 & 7.4 & 1.05 & 0.95 & 0.79 \\
\hline 2010 & 2313.4 & 1244.4 & 2669.3 & 2.51 & 2.60 & 2.81 & 58.1 & 32.3 & 75.1 & 1.05 & 0.95 & 0.79 \\
\hline 2011 & 1286.8 & 431.9 & 1675.5 & 2.25 & 2.17 & 2.83 & 29.0 & 9.4 & 47.4 & 0.84 & 0.76 & 0.72 \\
\hline 2012 & 2655.7 & 1022.8 & 3007.9 & 1.94 & 1.79 & 1.96 & 51.6 & 18.3 & 58.9 & 0.81 & 0.77 & 0.53 \\
\hline 2013 & 2860.0 & 1029.5 & 3571.7 & 1.58 & 1.69 & 1.60 & 45.1 & 17.4 & 57.3 & 0.96 & 1.01 & 0.63 \\
\hline 2014 & 2243.5 & 1161.6 & 2365.9 & 1.69 & 1.78 & 1.85 & 38.0 & 20.6 & 43.8 & 1.46 & 1.65 & 1.23 \\
\hline 2015 & 3117.4 & 1816.1 & 4048.2 & 1.77 & 1.73 & 1.80 & 55.2 & 31.3 & 72.9 & 1.04 & 1.04 & 0.81 \\
\hline
\end{tabular}

$\mathrm{NPKL}=$ nitrogen, phosphorus, potassium, and lime; check= no fertilizer applied; manure = beef manure applied every four years.

manure-treated plots and the inorganic N-treated plots. Correlation analysis was performed to determine the degree of linear relationship between TSN content in the manure and NPKL treatments (Table 3).

\section{Results and Discussion}

The results indicate that wheat grain yield was higher in the NPKL plot but not significantly different from that in the manure plot. Over the period reported in this study, the average grain yields recorded were 2510 and $2265 \mathrm{~kg} \cdot \mathrm{ha}^{-1}$ in NPKL and manure treatments, respectively (Table 3 ).

As was expected, grain yields from both treatments were significantly higher than those obtained in the control plot recorded at $1165 \mathrm{~kg} \cdot \mathrm{ha}^{-1}$. Lentz and Lehrsch [25] made similar observations where the contribution of manure to sugarbeet yield was either equal to or more than that of mineral $\mathrm{N}$ fertilizer depending on the application rate and timing. According to Eghball and Power [26], the observation that manure can produce grain yields equal to or greater than those of synthetic fertilizer application is true when the application rate is based on the correct $\mathrm{N}$ or $\mathrm{P}$ requirement. The manure application rate used in this study was based on the $\mathrm{N}$ requirement that was purposely matched with the $\mathrm{N}$ rate from the inorganic source (NPKL). Abdulmaliq et al. [27] recommended curing livestock manure for up to 6 weeks in order to obtain corresponding yield levels or even more than those of chemical fertilizer $\mathrm{N}$ application. This work shows that the manure soil amendment can sustainably support an intensive cereal-based cropping system when compared to inorganic sources. If the impact of manure and mineral $\mathrm{N}$ on crop yield is identical, it is possible to imagine that any environmental concerns associated with mineral $\mathrm{N}$ application could equally be experienced through manure soil amendment. Accordingly, the potential for environmental contamination needs to be assessed alongside increasing biomass or grain yield as the usefulness of manure application in crop production is considered. Therefore, the quality can be assessed by determining efficiency of $\mathrm{N}$ uptake and TSN accumulation over time. 
TABLE 3: Analysis of variance for wheat grain yield, grain N uptake, and TSN including summary of relationships between these variables in manure, check, and NPKL treatments (1990-2015) of Magruder Plots located at Stillwater in Oklahoma, USA.

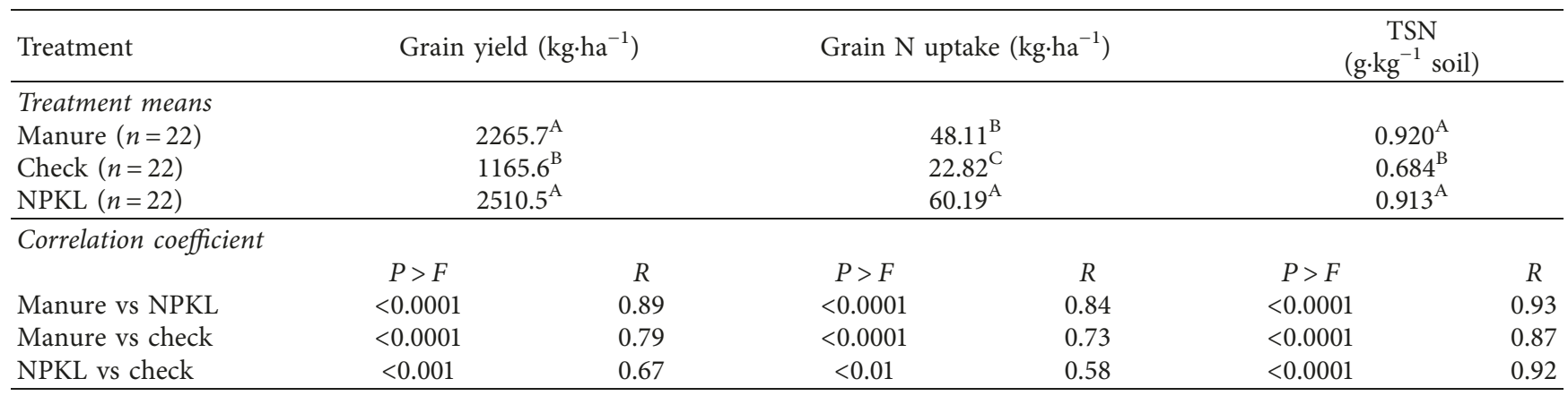

$\mathrm{NPKL}=$ nitrogen, phosphorus, potassium, and lime-treated plot; check = no fertilizer applied; manure = beef manure applied every four years; TSN = total soil nitrogen; treatment means within the same column with the same letter superscript are not significantly different (Tukey's HSD test).

There was a significant difference in grain $\mathrm{N}$ uptake among treatments. Grain N uptake varied from 3.5 to $78 \mathrm{~kg} \cdot \mathrm{ha}^{-1}$ in the manure treatment and 7.4 to $95 \mathrm{~kg} \cdot \mathrm{ha}^{-1}$ in the NPKL treatment (Table 2). The average grain $\mathrm{N}$ uptake of $60.2 \mathrm{~kg} \cdot \mathrm{ha}^{-1}$ in the NPKL treatment was significantly higher $(p<0.05)$ than that of $48.1 \mathrm{~kg} \cdot \mathrm{ha}^{-1}$ in the manure treatment. Grain N uptake in both the NPKL and manure treatments was significantly higher $(p<0.05)$ than that in the control treatment recorded at $22.8 \mathrm{~kg} \cdot \mathrm{ha}^{-1}$ (Table 3). The pattern of change in average grain $\mathrm{N}$ uptake over the study period for the two inputs was similar, as illustrated in Figure 1.

The high inconsistency in grain $\mathrm{N}$ uptake could be attributed to changes in the environmental variables especially rainfall and temperature over the study period. In some years, grain $\mathrm{N}$ uptake exceeded the amount of $\mathrm{N}$ in manure or inorganic fertilizer applied. For instance, in 1997, grain N uptake was 78 and $95 \mathrm{~kg} \cdot \mathrm{ha}^{-1}$ in the manure and NPKL treatments, respectively (Table 2). These values were higher than $67 \mathrm{~kg} \mathrm{~N} \cdot \mathrm{ha}^{-1}$ applied in the fertilizer. The same observation was made in 2005 where grain $\mathrm{N}$ uptake was 72 and $89 \mathrm{~kg} \cdot \mathrm{ha}^{-1}$ in the manure and NPKL treatments, respectively. This phenomenon is not unusual and can be explained by the random abiotic and/or biological events that favor the availability of $\mathrm{N}$ from sources other than fertilizer. The additional grain $\mathrm{N}$ comes from rainfall, symbiotic and nonsymbiotic fixation of atmospheric $\mathrm{N}_{2}$, and mineralization of soil organic matter. In an analysis that included data from 213 site-years, Dhital and Raun [19] reported that maize grain yield and the optimum fertilizer $\mathrm{N}$ rate varied from year to year. This suggested that the influence of the environment was reflected in resultant $\mathrm{N}$ uptake from soil amendment sources. In the current study, no significant grain yield differences were observed between the manure and NPKL treatments. Likewise, grain $\mathrm{N}$ uptake was expected to follow the same trend. Nonetheless, this was not observed. Increased grain yield in the manure treatment that was statistically equivalent with grain yield in the NPKL treatment could be due to increased $\mathrm{NH}_{4}-\mathrm{N}$ supply that is known to be more efficient [28]. Improved soil physical and/or biological properties in the manure treatment could also explain the matching yield levels with the NPKL treatment. Shirani et al. [29] attributed the increased biomass yield with manure amendments to improved soil physical properties. Similarly, Haynes and Naidu [30] noted that crop grain yield increases due to manure were likely a result of increased water-holding capacity, porosity, infiltration capacity, and hydraulic conductivity. Therefore, it is possible to have an identical wheat grain yield under manure and inorganic $\mathrm{N}$ treatments despite the low $\mathrm{N}$ uptake efficiency in the manure treatment.

At a constant $\mathrm{N}$ application rate of $67 \mathrm{~kg} \cdot \mathrm{ha}^{-1}$ for both manure and NPKL treatments, TSN content in these treatments recorded at 0.92 and $0.91 \mathrm{~g} \cdot \mathrm{kg}^{-1}$ of soil, respectively, was not significantly different $(p>0.05)$. The small difference in average TSN content $\left(0.01 \mathrm{~g} \cdot \mathrm{kg}^{-1}\right.$ of soil) between the manure and NPKL treatments demonstrates a comparable level of TSN content in these treatments (Table 3). However, significant differences were observed $(p<0.05)$ when compared to the check treatment $\left(0.68 \mathrm{~g} \cdot \mathrm{kg}^{-1}\right.$ of soil). Much as no significant differences were observed in TSN content between manure and NPKL treatments, linear regression over the study period showed a difference in the slope components of the regression equations (Figure 2). The slope for NPKL $\left(r^{2}=0.20\right)$ was not significant $(p>0.05)$, while that for manure $\left(r^{2}=0.24\right)$ was significant $(p<0.05)$. The significance in the rate of accumulation of TSN under manure treatment is due to comparatively low uptake efficiency of the manure N. Although there is a difference in significance of the slope components, a similar trend of TSN with time for the two inputs was observed (Figure 2). Additionally, the correlation coefficient $(r=0.93)$ showed a positive linear relationship and suggests comparable levels of TSN content in the manure- and NPKL-treated plots (Table 3). Similar observations were made in a long-term study by Aula et al. [13] where an average increase in TSN of $0.64 \mathrm{~g} \cdot \mathrm{kg}^{-1}$ was noted at three locations comparing two sets of samples (1993 and 2014) for treatments where high inorganic $\mathrm{N}$ was applied. Evidence that recovery of the applied $\mathrm{N}$ fertilizer was far below the quantity applied was present. In 2009, for instance, only 3.5 and $7.4 \mathrm{~kg} \mathrm{~N} \cdot \mathrm{ha}^{-1}$ were recovered in the grain in manure and NPKL treatments, respectively. This in part is a result of unfavorable environmental conditions for optimum plant uptake and that could also have been a result of a near total crop failure circumstance. Substantial quantities of the 


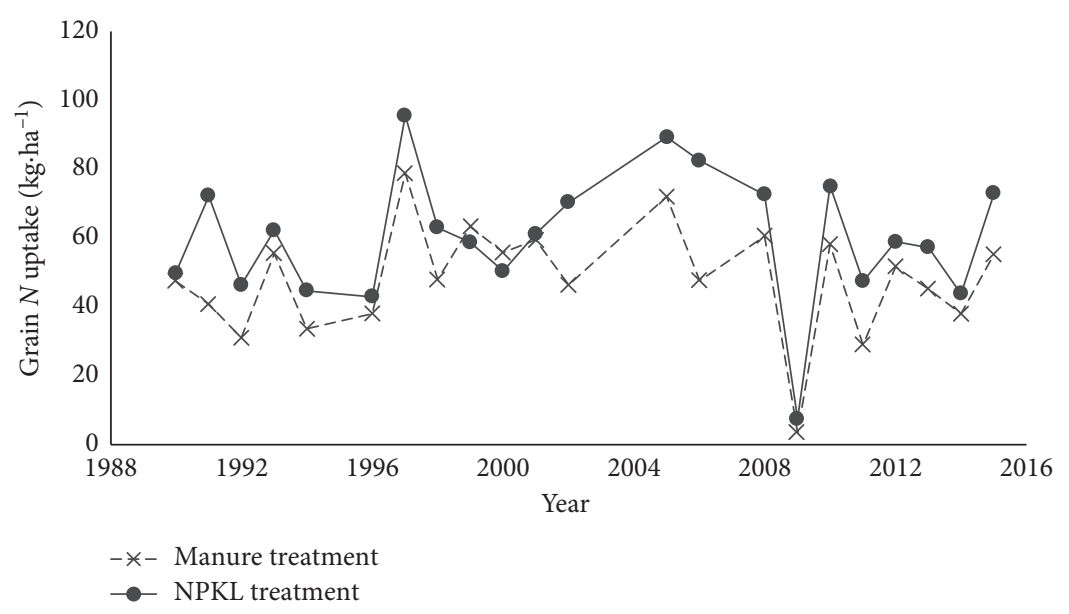

FIGURE 1: Changes in grain N uptake in manure and NPKL treatments, 1990-2015.

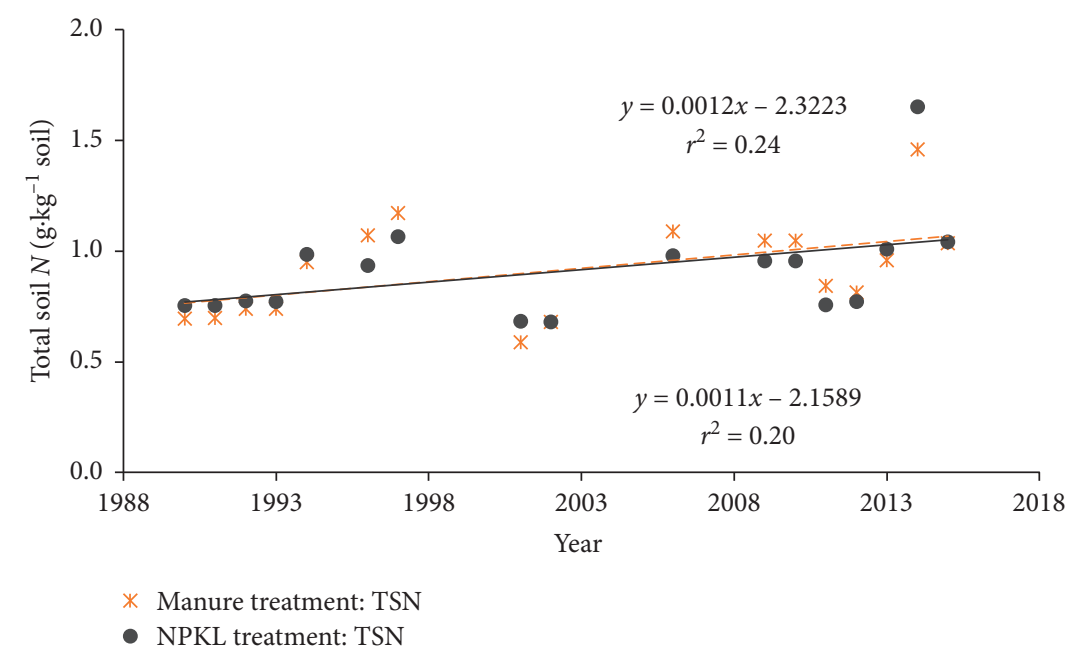

Figure 2: Total soil N accumulation in manure and NPKL treatments, 1990-2015.

applied $\mathrm{N}$ could be lost or immobilized within the soil system. If changes in the soil environment favor $\mathrm{N}$ immobilization, formation of soil organic $\mathrm{N}$ reduces crop uptake but favors TSN accumulation. Sarr et al. [18] reported a loss of $\mathrm{N}$ fertilizer between 55 and $60 \%$ and soil immobilization between 36 and $40 \%$ in a tracer $\mathrm{N}$ study. In the same study, $\mathrm{N}$ fixation from the inoculated plants increased $\mathrm{N}$ recovery by $81 \%$. This implies that atmospheric fixation may counter the effect of seasonal dynamics which dictates the availability of $\mathrm{N}$ for plant uptake and further explains the cause for the TSN accumulation despite low grain $\mathrm{N}$ recovery.

\section{Conclusion}

From 1990 to 2015, N uptake was 20\% greater in the NPKL treatment than manure treatment, while grain yield from the two sources (manure and NPKL) was not significantly different. Manure N uptake was notably lower compared to the uptake from inorganic $\mathrm{N}$ sources as it is, in most cases, not readily available for immediate crop uptake. This observation is similar to that by $\mathrm{Ma}$ et al. [31] who reported a significantly lower manure $\mathrm{N}$ uptake efficiency compared to inorganic $\mathrm{N}$ uptake efficiency even when grain yield levels were comparable for the two input sources. It is also important to note that the observation made in this study indicates a strong influence of the environment on the uptake of $\mathrm{N}$ from both manure and inorganic sources evidenced by high variation in this parameter. A positive trend of TSN accumulation in soil over time was similar for organic and inorganic sources. Animal manure can produce similar yield levels to inorganic $\mathrm{N}$ fertilizer despite the low $\mathrm{N}$ uptake efficiency. The fact that identical quantities of $\mathrm{N}$ were supplied from the two input sources, low $\mathrm{N}$ uptake from the manure $\mathrm{N}$ source could suggest a potential for environmental pollution. Appropriate timing and application rate of manure $\mathrm{N}$ sources could optimize crop use efficiency and limit potential threat to the environment.

\section{Data Availability}

The dataset used for this study was obtained from a longterm winter wheat fertility experiment "Magruder Plots" 
located at Stillwater and are available from the corresponding author upon request.

\section{Conflicts of Interest}

The authors declare that they have no conflicts of interest.

\section{References}

[1] J. M. Powell, S. Fernández-Rivera, P. Hiernaux, and M. D. Turner, "Nutrient cycling in integrated rangeland/ cropland systems of the Sahel," Agricultural Systems, vol. 52, no. 2-3, pp. 143-170, 1996.

[2] B. Singh and Y. Singh, "Reactive nitrogen in Indian agriculture: inputs, use efficiency and leakages," Current Science, article 00113891, vol. 94, no. 11, pp. 1382-1393, 2008.

[3] S. R. Carpenter, N. F. Caraco, D. L. Correll, R. W. Howarth, A. N. Sharpley, and V. H. Smith, "Nonpoint pollution of surface waters with phosphorus and nitrogen," Ecological Applications, vol. 8, no. 3, pp. 559-568, 1998.

[4] G. P. Robertson and S. M. Swinton, "Reconciling agricultural productivity and environmental integrity: a grand challenge for agriculture," Frontiers in Ecology and the Environment, vol. 3, no. 1, pp. 38-46, 2005.

[5] J. A. Camargo and Á Alonso, "Ecological and toxicological effects of inorganic nitrogen pollution in aquatic ecosystems: a global assessment," Environment International, vol. 32, no. 6, pp. 831-849, 2006.

[6] K. Mengel, "Turnover of organic nitrogen in soils and its availability to crops," Plant and Soil, vol. 181, no. 1, pp. 83-93, 1996.

[7] G. P. Robertson and P. M. Groffman, "Nitrogen transformations," in Soil Microbiology, Ecology and Biochemistry, pp. 341-364, 3rd edition, 2007.

[8] G. Torstensson, H. Aronsson, and L. Bergström, "Nutrient use efficiencies and leaching of organic and conventional cropping systems in Sweden," Agronomy Journal, vol. 98, no. 3, pp. 603-615, 2006.

[9] C. Chang and T. Entz, "Nitrate leaching losses under repeated cattle feedlot manure applications in southern Alberta," Journal of Environment Quality, vol. 25, no. 1, pp. 145-153, 1996.

[10] Y. Wang, X. Zhang, and C. Huang, "Spatial variability of soil total nitrogen and soil total phosphorus under different land uses in a small watershed on the Loess Plateau, China," Geoderma, vol. 150, no. 1-2, pp. 141-149, 2009.

[11] J. M. Bremner and C. S. Mulvaney, "Nitrogen-total 1," in Methods of Soil Analysis. Part 2. Chemical and Microbiological Properties Methodsofsoilan, pp. 595-624, American Society of Agronomy, Madison, WI, USA, 1982.

[12] G. Xu, Z. Li, and P. Li, "Fractal features of soil particle-size distribution and total soil nitrogen distribution in a typical watershed in the source area of the middle Dan River, China," Catena, vol. 101, pp. 17-23, 2013.

[13] L. Aula, N. Macnack, P. Omara, J. Mullock, and W. Raun, "Effect of fertilizer nitrogen $(\mathrm{N})$ on soil organic carbon, total $\mathrm{N}$, and soil $\mathrm{pH}$ in long-term continuous winter wheat (Triticum aestivum L.)," Communications in Soil Science and Plant Analysis, vol. 47, no. 7, pp. 863-874, 2016.

[14] P. Omara, N. Macnack, L. Aula, and B. Raun, "Effect of longterm beef manure application on soil test phosphorus, organic carbon, and winter wheat yield," Journal of Plant Nutrition, vol. 40, no. 8, pp. 1143-1151, 2017.
[15] J. M. H. Knops and D. Tilman, "Dynamics of soil nitrogen and carbon accumulation for 61 years after agricultural abandonment," Ecology, vol. 81, no. 1, pp. 88-98, 2000.

[16] R. L. Westerman, R. K. Boman, W. R. Raun, and G. V. Johnson, "Ammonium and nitrate nitrogen in soil profiles of long-term winter wheat fertilization experiments," Agronomy Journal, vol. 86, no. 1, pp. 94-99, 1994.

[17] W. R. Raun and G. V. Johnson, "Improving nitrogen use efficiency for cereal production," Agronomy Journal, vol. 91, no. 3, pp. 357-363, 1999.

[18] P. S. Sarr, J. W. Okon, D. A. B. Begoude et al., "Symbiotic N2fixation estimated by the ${ }^{15} \mathrm{~N}$ tracer technique and growth of Pueraria phaseoloides (Roxb.) Benth. inoculated with Bradyrhizobium strain in field conditions," Scientifica, vol. 2016, Article ID 7026859, 10 pages, 2016.

[19] S. Dhital and W. R. Raun, "Variability in optimum nitrogen rates for maize," Agronomy Journal, vol. 108, no. 6, pp. 2165-2173, 2016.

[20] H. M. El-Sharkawi, "Effect of nitrogen sources on microbial biomass nitrogen under different soil types," ISRN Soil Science, vol. 2012, Article ID 310727, 7 pages, 2012.

[21] M. F. Jurgensen, "Relationship between nonsymbiotic nitrogen fixation and soil nutrient status-a review," Journal of Soil Science, vol. 24, no. 4, pp. 512-522, 1973.

[22] K. Girma, S. L. Holtz, D. B. Arnall, B. S. Tubaña, and W. R. Raun, "The Magruder plots: untangling the puzzle," Agronomy Journal, vol. 100, no. 3, pp. S-11, 2008.

[23] J. S. Schepers, D. D. Francis, and M. T. Thompson, "Simultaneous determination of total $\mathrm{C}$, total $\mathrm{N}$, and ${ }^{15} \mathrm{~N}$ on soil and plant material," Communications in Soil Science and Plant Analysis, vol. 20, no. 9-10, pp. 949-959, 1989.

[24] SAS Institute Inc, Base SAS 9.4 Procedures Guide: Statistical Procedures, SAS Institute Inc, Cary, NC, USA, IInd edition, 2013.

[25] R. D. Lentz and G. A. Lehrsch, "Nitrogen availability and uptake by sugarbeet in years following a manure application," International Journal of Agronomy, vol. 2012, Article ID 120429, 12 pages, 2012.

[26] B. Eghball and J. F. Power, "Phosphorus- and nitrogen-based manure and compost applications," Soil Science Society of America Journal, vol. 63, no. 4, pp. 895-901, 1999.

[27] S. Y. Abdulmaliq, Y. A. Abayomi, M. O. Aduloju, and O. Olugbemi, "Effects of curing period of livestock droppings on the growth and yield of okra (Abelmoschus esculentus L.) varieties," International Journal of Agronomy, vol. 2016, Article ID 3513954, 7 pages, 2016.

[28] S. R. Olsen, "The role of organic matter and ammonium in producing high corn yields," in The Role of Organic Matter in Modern Agriculture, pp. 29-54, Springer, Dordrecht, Netherlands, 1986.

[29] H. Shirani, M. A. Hajabbasi, M. Afyuni, and A. Hemmat, "Effects of farmyard manure and tillage systems on soil physical properties and corn yield in central Iran," Soil and Tillage Research, vol. 68, no. 2, pp. 101-108, 2002.

[30] R. J. Haynes and R. Naidu, "Influence of lime, fertilizer and manure applications on soil organic matter content and soil physical conditions: a review," Nutrient Cycling in Agroecosystems, vol. 51, no. 2, pp. 123-137, 1998.

[31] B. L. Ma, L. M. Dwyer, and E. G. Gregorich, "Soil nitrogen amendment effects on nitrogen uptake and grain yield of maize," Agronomy Journal, vol. 91, no. 4, pp. 650-656, 1999. 


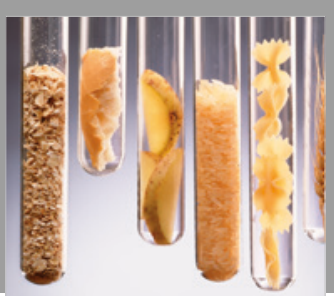

International Journal of Food Science

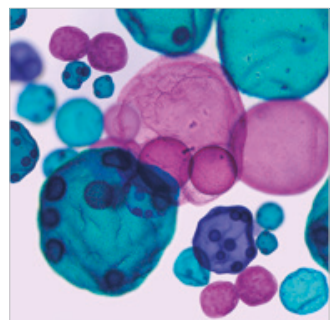

International Journal of Microbiology
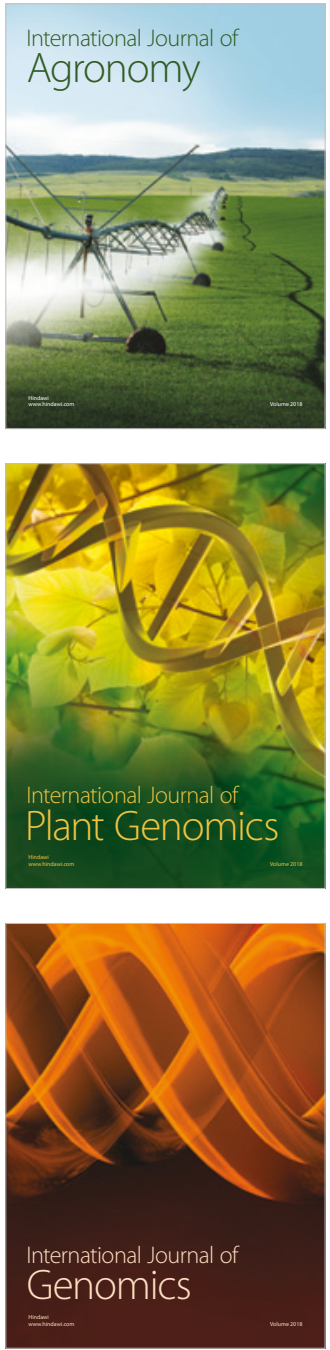

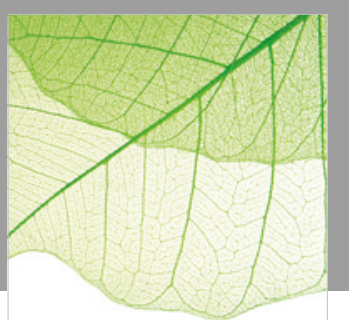

Journal of Botany
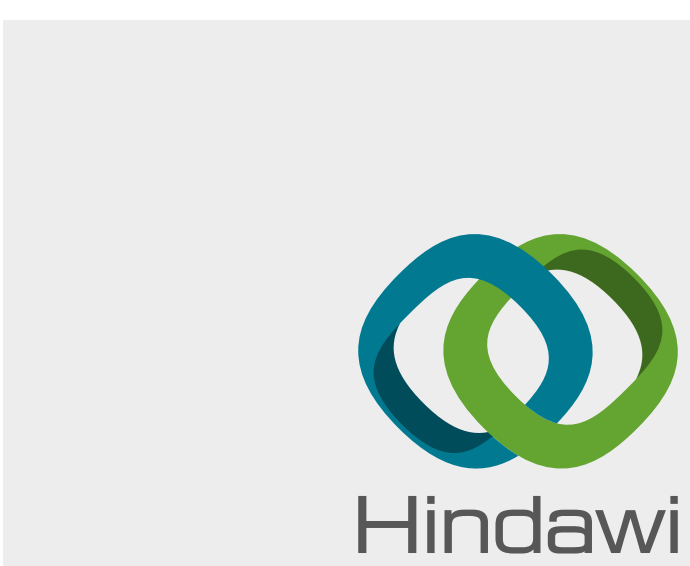

Submit your manuscripts at

www.hindawi.com
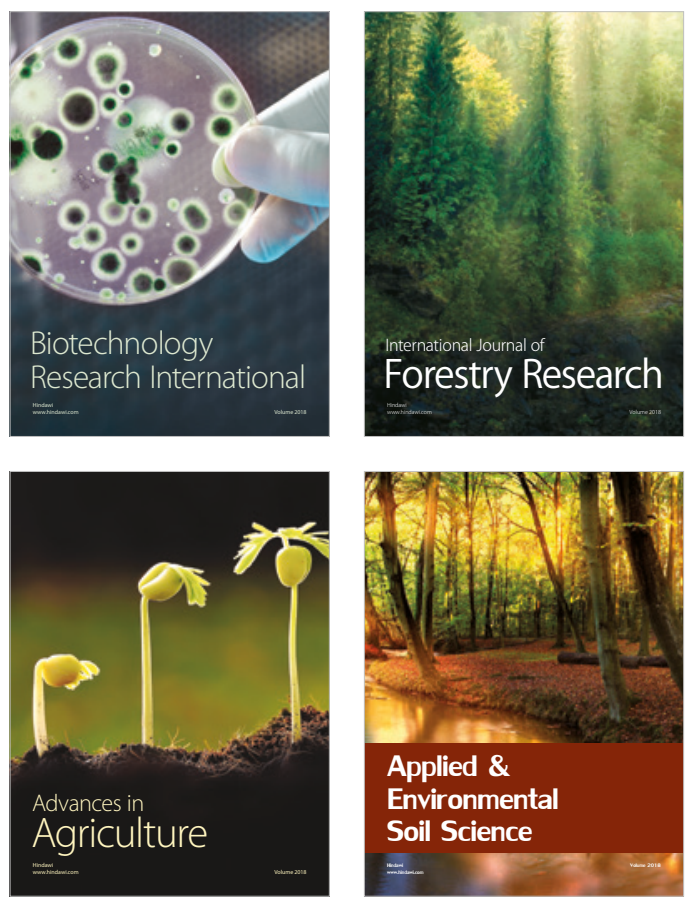

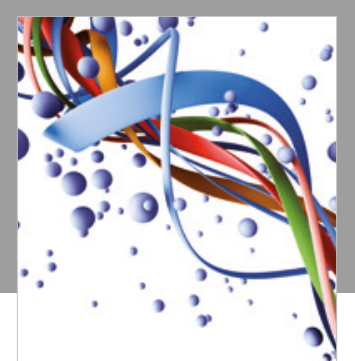

Scientifica

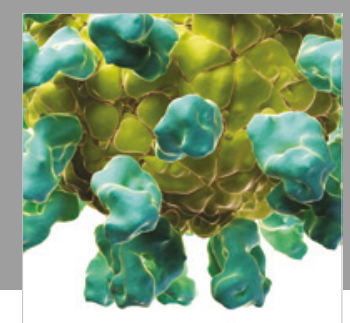

Veterinary Medicine International

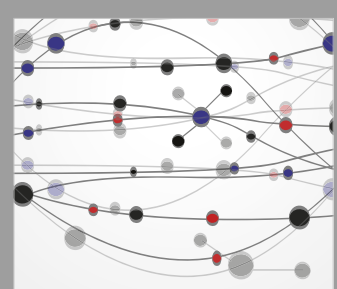

The Scientific World Journal
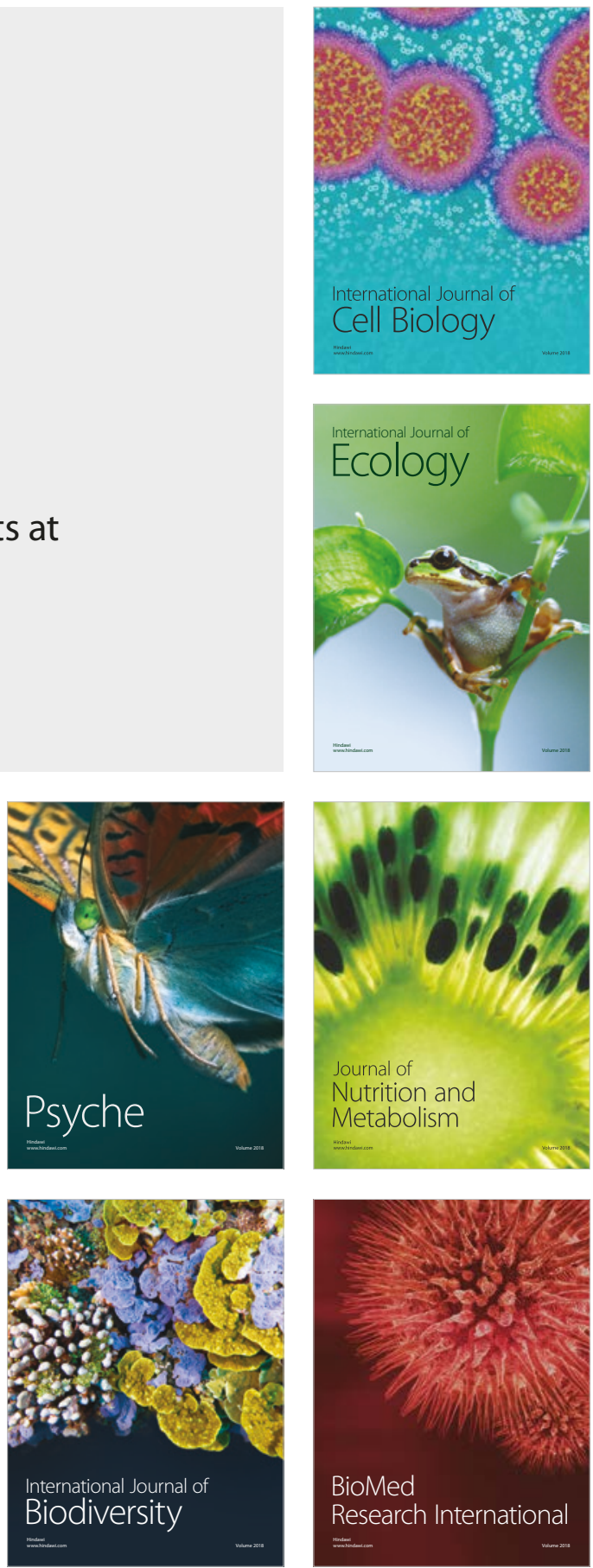